\title{
Interaction of cysteine-rich cationic antimicrobial peptides with intact bacteria and model membranes*
}

\author{
Krisztina Nagy ${ }^{1}$, Kata R. Mikuláss², Attila G. Végh ${ }^{1}$ Attila Kereszt², Éva Kondorosi², \\ György Váró ${ }^{1}$ and Zsolt Szegletes ${ }^{1}$ \\ 1 Institute of Biophysics, Biological Research Centre of Hungarian Academy of Sciences, Temesvári krt. 62., Szeged, Hungary \\ 2 Institute of Biochemistry, Biological Research Centre of Hungarian Academy of Sciences, Temesvári krt. 62., Szeged, Hungary
}

\begin{abstract}
Antimicrobial peptides are small proteins that exhibit a broad spectrum of antimicrobial activity. Their chemical structure allows them to interact (attach and insert) with membranes. The fine details about this interaction and their mode of action are not fully clarified yet. In order to better understand this mechanism, we have performed in situ atomic force microscopy studies using two types of nodule specific cysteine-rich NCR peptides on Escherichia coli bacteria and on natural purple membrane. On intact bacteria, both NCR247 and NCR335 caused increase in the surface roughness, indicating the damage of the bacterial cell envelope. In case of the tightly packed purple membrane, it is clear that the peptides prefer to disrupt the border of the disks indicating a strong lipid preference of the interaction. These results verify the concept that the first target of NCR peptides is probably the bacterial cell envelope, especially the lipid matrix.
\end{abstract}

Key words: Antimicrobial peptide - Atomic force microscopy - Purple membrane

\section{Introduction}

Antimicrobial peptides (AMP) are unique molecules produced by almost all living organisms (from microbes to plants and animals) (Maróti et al. 2011). Generally they have a key role in the innate immunity, because they exhibit a broad spectrum of antimicrobial activity against both Gram-positive and Gram-negative bacteria and fungi (Boman 1995). Common features of these peptides are their small size (less than 100 amino acids) and that they are ribosomally synthesized. AMPs exist with a large variety of chemical structures, but all of them have an amphipathic nature, allowing the interaction (attachment and insertion) with biological membranes (Vaara and Vaara 1983; Epand and Vogel 1999; Huang 2006). The most general mode of their action is the disruption of microbial membranes or

\footnotetext{
*This article was presented at the Regional Biophysics Conference, organised by The Slovak Biophysical Society in Smolenice, May 15-20, 2014.

Correspondence to: Krisztina Nagy, Institute of Biophysics, Biological Research Centre of Hungarian Academy of Sciences, 6726 Temesvári krt. 62., Szeged, Hungary

E-mail: nagy.krisztina@brc.mta.hu
}

induction of pore formation resulting in the lysis of the cells (Teixeira et al. 2012). After getting through the membrane, peptides may have intracellular targets, such as DNA, RNA or specific proteins (Ganz 2003; Brogden 2005; Sochacki et al. 2011). The details by which these peptides associate and permeabilize microbial cell membranes are not entirely clarified yet. However, if we better understood the mode of action of AMPs, it would provide new strategies for combating infections and evolving antibiotic resistance (Peters et al. 2010).

A large gene family of AMP-like molecules called nodulespecific cystein-rich (NCR) peptides has been identified in some legumes, such as Medicago truncatula (M. truncatula) (Mergaert et al. 2003). These peptides are produced in the symbiotic organs termed root nodules and are targeted to the symbiotic bacteria that are wrapped in plant membranes and reside in the nodule cells (Van de Velde et al. 2010). The peptides have a key role in the establishment of the nitrogen-fixing symbiosis by directing the differentiation of the symbiont, Sinorhizobium meliloti (S. meliloti) (Mergaert et al. 2006; Van de Velde et al. 2010; Farkas et al. 2014). The cationic sub-group of the NCR peptides has antimicrobial effect. These peptides are potent against a variety of bacterial strains (Tiricz et al. 2013) as well as against unicellular 
and filamentous fungi (Ördögh et al. 2014). The structure of NCRs is similar to the mammalian defensins, which are also small secreted cationic peptides containing cysteine residues and disulphide bridges (Ganz 2003). It has been shown that human defensins attack the outer and inner membrane of metabolically active and growing bacteria (Lehrer et al. 1989). During exposure of bacteria and fungi to chemically synthetized mature NCR247 and NCR335 cationic peptides, changes in the membrane permeability could be detected, but the proper mode of their action is still unknown (Tiricz et al. 2013; Ördögh et al. 2014). These two peptides possess special chemical properties that make them suitable for combating against microorganisms. NCR247 is the shortest and probably the most studied one among NCRs. Its amino acid sequence is unique, and it has an extreme hydrophilic character with a hydropathy value of $19.4 \mathrm{~kJ} / \mathrm{mol}$ (Farkas et al. 2014). This could also be a reason for exerting multiple activities, like in the case of the multifunctional antimicrobial peptides PR-39 and LL-37. NCR335, having the highest pI value, is the most cationic member of the NCR family. Based on this characteristic it may be the most efficient bactericid. There is not so much information about their tertiary structure. Regarding NCR247, it has been proved that the cysteine residues, the net positive charge and the precise S-S bridge configurations are necessary for the full activity of the peptide (Haag et al. 2012).

Atomic force microscopy (AFM) is a versatile tool in studying cells and biomolecules under in situ physiological conditions at high resolution (Dufrene 2008). The technique enables monitoring cellular events such as cell growth and division (Touhami et al. 2004). Besides imaging, changes in the viscoelastic properties of individual cells can be measured. Differences between the bacterial cell envelope of Gram-negative and Gram-positive bacteria could be detected (Vadillo-Rodriguez et al. 2009). The effect of external drugs on the morphology and elastic properties of single cells was tracked over time (Francius et al. 2008; Lu et al. 2014). By modifying the AFM tip, intermolecular interactions could also be revealed between the surface of living bacteria and antimicrobial drugs (Dague et al. 2007).

Besides monitoring intact bacteria, AFM may provide other possibilities to investigate peptide-membrane interactions. Planar supported bilayers were built up (Dufrene and Lee 2000; Pilbat et al. 2007), or natural membranes isolated from bacteria and anchored to flat surfaces (Müller et al. 2000; Végh et al. 2011) were used as models of biological membranes of bacterial cells. The effect of different cationic antimicrobial peptides has already been studied on planar lipid bilayers of different compositions (Shaw et al. 2008; Végh et al. 2011).

According to the "membrane domains" and "lipid raft" concept (Simons and Ikonen 1997) of biological membranes, proteins may not diffuse freely in the lipid bilayer (as it is suggested in the fluid mosaic model), but are confined to specific domains (Sonnino and Prinetti 2013). These types of functional microdomains (proteins associated with lipid rafts) have been identified not only in eucariotic cells, but in some bacterial strains, as well (López et al. 2010; Barák et al. 2013). Therefore membrane models containing rafts and domains are also required when studying interaction of peptides with biological membranes. Phase-separated supported bilayers were used as models of lipid rafts and membrane microdomains when the effect of the cationic peptide indolicidin was investigated. Shaw et al. reported a concentration- and lipid-dependent mode of action of indolicidin, which suggests a raft-specific interaction between the peptide and the membrane (Shaw et al. 2006). A well-known example of naturally occurring macroscopic membrane domains is the purple membrane of Halobacterium salinarum (H. salinarum), which in vivo exists in $2 \mathrm{D}$ crystalline patches. It consists of bacteriorhoodopsin trimers tightly packed into lipids of the fluid bilayer (Lanyi 2004). The structure of the purple membrane is well characterized: it contains $75 \%$ protein (only bacteriorhodopsin) and 25\% lipid (Oesterhelt and Stoeckenius 1971). The detailed structure of purple membranes and bacteriorhodopsin trimers could be detected on AFM images (Müller et al. 1995, 1999, 2000) and dynamic changes during function in the purple membrane were identified too (Casuso et al. 2009; Yamashita et al. 2009). The above mentioned properties of the purple membrane of $H$. salinarum allow us to use it as a model of lipid rafts. Studying the effect of AMPs on purple membrane patches would provide a deeper understanding of the mode of AMP action on bacterial cell envelope.

In this paper we present an in situ AFM study to reveal the details of interactions of small cationic NCR247 and NCR335 peptides with intact bacteria and native purple membrane patches. The effect of the plant-derived NCR AMPs on natural membranes was compared to the effect of the 13-amino acid cationic indolicidin (ILPWKWPWWPWRR-NH $\mathrm{pI}=12.51$ ), which is a member of the cathelicidin family of AMPs and was isolated from bovine neutrophils (Selsted et al. 1992).

\section{Materials and Methods}

\section{Antimicrobial peptides}

NCR247 $\left(\mathrm{NH}_{2}\right.$-RNGCIVDPRCPYQQCRRPLYCRRR; $\mathrm{mw}=3.0 \mathrm{kDa} ; \mathrm{pI}=10.15)$ and NCR335 $\left(\mathrm{NH}_{2}-\mathrm{RLNTT}-\right.$ FRPLNFKMLRFWGQNRNIMKHRGQKVHFSLILSDCKTNKDCPKLRRANVRCRKSYCVPI; $\mathrm{mw}=7.7 \mathrm{kDa}$; $\mathrm{pI}=11.22$ ) peptides were chemically synthetized and provided by ProteoGenyx Inc. (France) in a high (>95\%) purity. 


\section{Bacterial cell cultures}

For testing the antimicrobial activity of NCR peptides on bacteria, we used Eschericia coli (E. coli) MDS42 strain (Pósfai et al. 2006). Cells were grown overnight in $10 \mathrm{ml}$ lysogeny broth (LB) medium at $37^{\circ} \mathrm{C}$ in glass flask in an incubator shaker (250 rpm). Overnight culture was diluted back in the morning, and cells at a density of $\mathrm{OD}_{600}$ (optical density measured at $600 \mathrm{~nm}$ ) around 0.1 (approximately $10^{7} \mathrm{cell} / \mathrm{ml}$ ) were centrifuged (13000 rpm, $1 \mathrm{~min}$, two times), washed and resuspended in potassium-phosphate buffer $(10 \mathrm{mM}, \mathrm{pH}=7.0)$. Bacteria cultures were incubated for 3 hours in buffer containing either 3.2 $\mu$ M NCR335 or 16.6 $\mu$ M NCR247 peptides. Serial dilutions of the treated cell suspensions were plated to determine the number of surviving cells by counting the number of colony forming units (CFU). We repeated the colony suspension experiment three times, using three biological parallels each time. As a control, E. coli cell culture incubated for 3 hours in phosphate buffer without peptide were also plated.

The applied concentrations were determined based on the minimal inhibitory concentration (MIC) of NCR247 and NCR335 on E. coli. MIC values were determined by broth dilution method in 96-well microliter plate format (Lázár et al. 2013), and we used concentrations just above the MIC values (1.2-fold the MIC) during the experiments. All the chemicals used for culturing bacteria were provided by Sigma-Aldrich Corporation.

\section{Atomic force microscopy}

AFM measurements were carried out with an Asylum MFP3D head and controller (Asylum Research, Santa Barbara, CA, USA). The driver program MFP-3D Xop was written in IGOR Pro Software (Wavemetrics, Lake Oswego, OR, USA). For imaging bacteria, gold coated silicon nitride rectangular cantilevers were used with a typical spring constant of $0.03 \mathrm{~N} / \mathrm{m}$, tip radius around $30 \mathrm{~nm}$ (BL-RC150 VB, Olympus Optical Co. Ltd., Tokyo, Japan). In case of purple membrane patches another type of silicon nitride cantilevers (BL-AC40 TS, Olympus Optical Co. Ltd., Tokyo, Japan) were used with $0.09 \mathrm{~N} / \mathrm{m}$ spring constant.

The spring constant for each cantilever was determined by thermal calibration (Hutter and Bechhoefer 1993; Butt and Jaschke 1995; Florin et al. 1995). Measurements were carried out in tapping mode in liquid. Typically, $512 \star 512$ point scans were taken at $0.4 \mathrm{~Hz}$ scan rate. Both the trace and retrace images were recorded and compared. Experiments were repeated 3-5 times for both peptide treatments.

\section{Sample preparation and solutions}

For the measurements, freshly cleaved $1 \times 1 \mathrm{~cm}$ mica (SPI-Chem $^{\mathrm{TM}}$ Mica Sheets, Structure Probe, Inc., West
Chester, PA, USA) surfaces were used as supports for the bacteria. The negatively charged mica surface was covered by poly-(L-lysine) (PLL), creating a suitable surface for the attachment of Gram-negative bacteria, such as E. coli (Meyer et al. 2010). After washing the PLL coated sample with $10 \mathrm{mM}$ potassium-phosphate buffer $(\mathrm{pH}=7)$, the bacteria were let to adhere to the surface for 40 minutes from solution. The excess of bacteria was washed away, and the AFM experiments were carried out in the same potassium-phosphate buffer. Before the AFM measurements, the viability of the adsorbed cells was checked by using LIVE/DEAD BacLight ${ }^{\mathrm{TM}}$ Bacterial Viability Kit (Invitrogen Corporation). Propidium-iodide (PI) is able to penetrate only damaged cell membranes, while SYTO 9 enters cells even if they are healthy with an intact cell envelope. When both dyes are present, PI causes a reduction in the SYTO 9 stain fluorescence therefore, with an appropriate mixture of the two stains PI can be used to detect membrane disintegrity. Bacteria with intact cell membranes stain fluorescent green, whereas bacteria with damaged membranes stain fluorescent red. Height and amplitude images of the same cells were taken before and after the peptide treatment. After checking the healthy, non-treated cells, NCR247 or NCR335 antimicrobial peptide was added, and the morphology changes of the same cells were followed in time.

Purple membrane was prepared from Halobacterium salinarum according to the method of Oesterhelt and Stoeckenius (Oesterhelt and Stoeckenius 1974). Membrane patches were also adsorbed onto freshly cleaved, $\mathrm{Ca}^{2+}$ treated mica surfaces and measured in buffer (10 mM TRIS, $150 \mathrm{mM}$ $\mathrm{NaCl}, \mathrm{pH}=8$ ).

\section{Results}

In situ atomic force microscopy experiments were performed to investigate the interaction of NCR247 and NCR335 antimicrobial peptides with intact Gram-negative bacteria and natural purple membranes in details. The MIC values of the peptides were determined $(13.6 \mu \mathrm{M}$ for NCR247 and $2.5 \mu \mathrm{M}$ for NCR335), and the relative concentration to the MIC was kept constant. We used concentrations 1.2-fold the MIC values in case of both peptide treatment during all experiments.

In order to image living bacteria, E. coli target cells were immobilized by using attractive electrostatic interactions. The chemical modification of surfaces with a positive layer of PLL is a common way to increase the adherence of bacteria from suspensions (Meyer et al. 2010). To test the viability of the immobilized cells, we employed two nucleic acid stains: green fluorescent SYTO 9 and red fluorescent PI (Fig. 1). Figure 1 shows characteristic fluorescence 
A

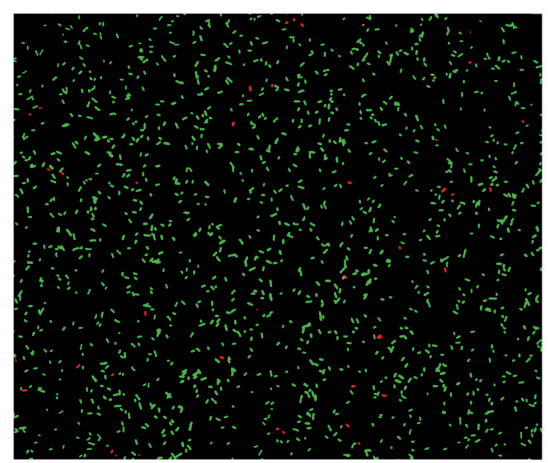

B

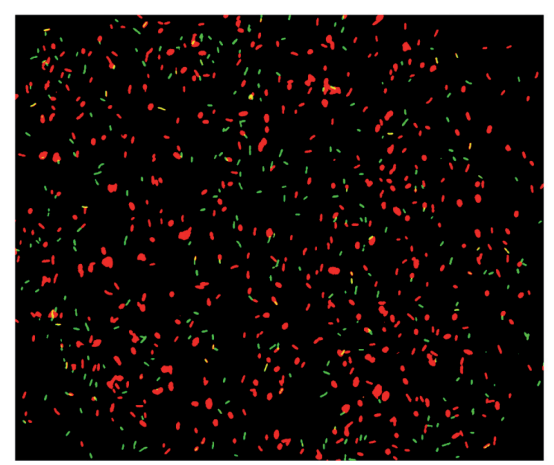

C

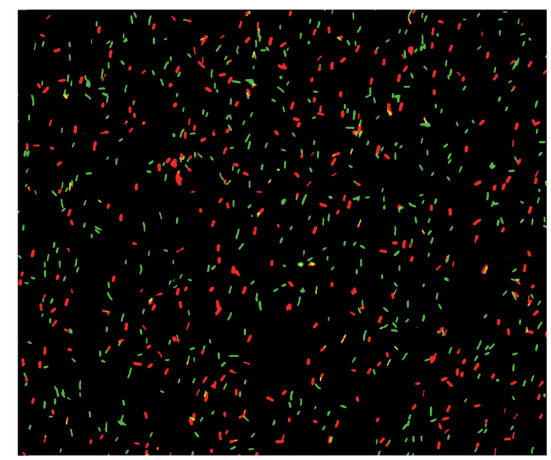

Figure 1. Fluorescence images taken of E. coli bacteria (magnification $\times 400$ ) attached to PLL layer before any treatment $(\mathbf{A})$ and after a 3 hour treatment of $3.2 \mu \mathrm{M}$ NCR335 (B) and $16.6 \mu \mathrm{M}$ NCR247 (C) antimicrobial peptide. Green and red fluorescence correspond to the LIVE/DEAD staining of green-fluorescent SYTO 9 and red-fluorescent PI.

images taken of $E$. coli cells at the beginning of an experiment (Fig. 1A) and after a 3-hour long NCR335 or NCR247 peptide treatment (Fig. 1B,C). These images agree well with CFU data obtained with peptide-treated E. coli cultures (Fig. 2). Both NCR247 and NCR335 showed antibacterial activity against $E$. coli, but with different efficiency. While the cell number decreased with only one order of magnitude during 3 hours of NCR247 treatment, NCR335 totally blocks the growth of the bacterial culture (Fig. 2). These results are in good agreement with data published by Tiricz et al. (2013). Control experiments were performed by measuring CFU without peptide treatment, and we found no harmful effect coming from the pure phosphate buffer during 3 hours.

High-resolution AFM images of E. coli were obtained in situ without the use of fixing agents. The same cells

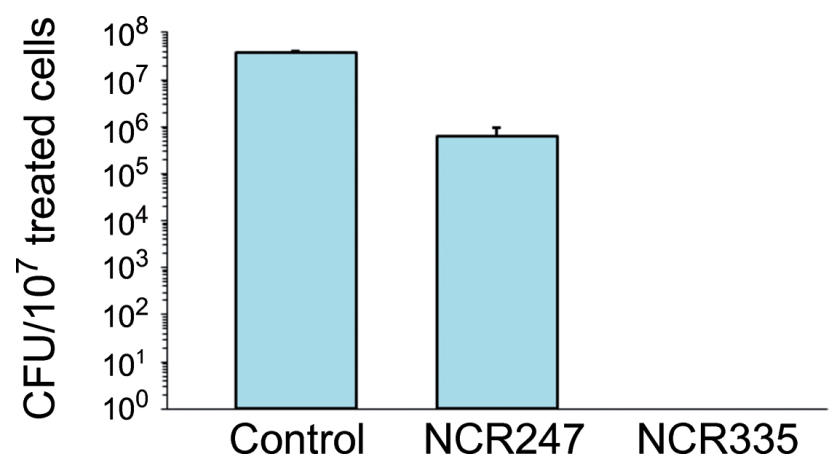

Figure 2. Antimicrobial activity of $16.6 \mu \mathrm{M}$ NCR2 47 and $3.2 \mu \mathrm{M}$ NCR335 peptides: cell number is estimated from the number of colonies (CFU) formed from $10^{7}$ cells after 3 hours of each peptide treatment. As a control, a bacterial culture incubated in pure phosphate buffer for 3 hours was also plated. Error bars of 8 colony suspensions are presented. were imaged before and after peptide treatments (Fig. 3 and 4). Changes in the morphology of the cell envelope as a consequence of peptide action could be detected. The amplitude (Fig. 3A,D) and height images (Fig. 3B,E) show changes in roughness of the cell envelope after a 3-hour treatment with $16.6 \mu \mathrm{M}$ of NCR247 peptide which may be an evidence for membrane permeabilization effect by this molecule. The increased surface roughness compared to healthy untreated cells is shown by the height profiles in Fig. 3C and 3F. The height of the imaged cells didn't change, but small protruding structures appeared on the initially smooth cell surface. Similar, but stronger effect could be detected when using $3.2 \mu \mathrm{M}$ NCR335 solution (Fig. 4). The high efficiency of NCR335 was also demonstrated by the large number of detaching cells from the PLL surface during the scanning procedure. It was almost impossible to find the same cells before and after NCR335 peptide treatments.

We have also investigated the effect of NCR247 and NCR335 peptides on natural purple membrane patches prepared from $H$. salinarum and deposited directly on $\mathrm{Ca}^{2+}$ covered mica surface. The NCR247 $(16.6 \mu \mathrm{M})$ and NCR335 $(3.2 \mu \mathrm{M})$ peptides caused distinct changes in the membrane structure that could be followed on the AFM scans. Height images and characteristic height profiles measured in buffer are shown in Fig. 5 and 6. NCR247 aggregated in small spots on the membrane surface and small protruding structures appeared at the edges (Fig. 6), similarly to the effects observed in the case of indolicidin (Fig. 7). The height of this protruding layer at the membrane edges is about $3-4 \mathrm{~nm}$ that is approximately the half of the normal height of the purple membrane $(\sim 6-8 \mathrm{~nm})$. In contrast the NCR335 treatment (Fig. 5) caused the appearance of huge aggregations on the membrane surface and no "membrane-thinning" effect could be detected. 


\section{Before treatment}

A

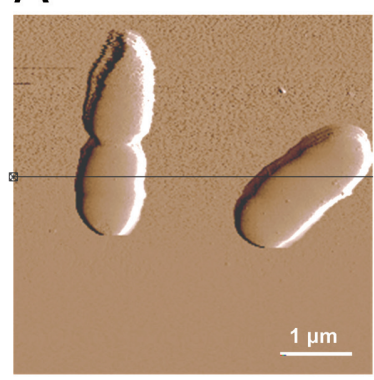

B

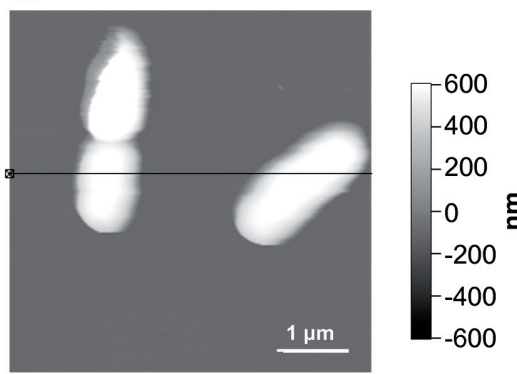

reatment
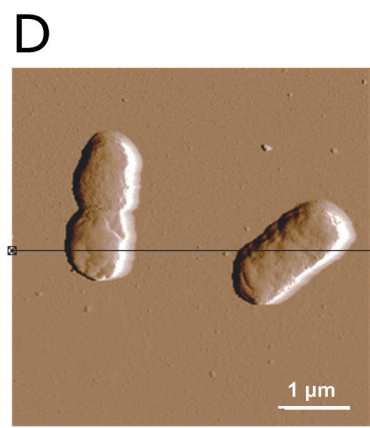

$\mathrm{E}$

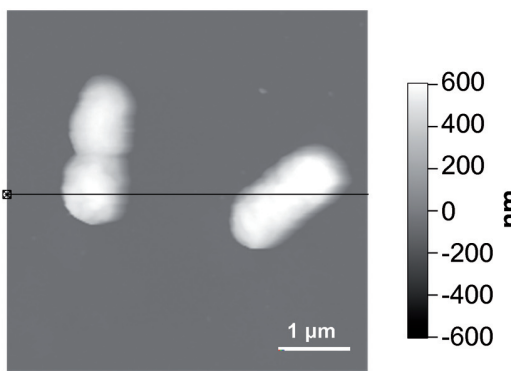

C

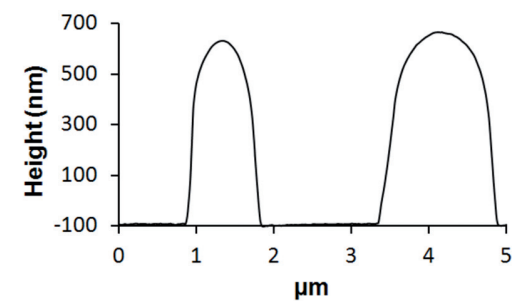

$\mathrm{F}$

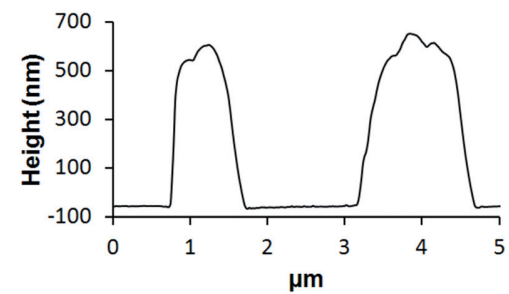

Figure 3. The effect of NCR247 peptide of $16.6 \mu \mathrm{M}$ concentration on the morphology of intact E. coli cells during a typical 3-hour experiment. Amplitude and height images are shown together with height profiles corresponding to the black line assigned on the images. Images $\left(5 \times 5 \mu \mathrm{m}^{2}\right)$ of the same cells were taken before $(\mathbf{A}, \mathbf{B}, \mathbf{C})$ and after $(\mathbf{D}, \mathbf{E}, \mathbf{F})$ the peptide treatment.

\section{Discussion}

Small cationic peptides produced by $M$. truncatula might have the potential to be used as antibiotic agents, in future clinical treatments. In this study, we investigated the interaction of two NCR peptides with biological membranes in order to better understand the proper mechanism of their action. The antibiotic activity of NCR2 47 and NCR335 has recently been revealed (Tiricz et al. 2013; Ördögh et al. 2014). The two peptides differ in their molecular weight, length and pI value. The estimated net charges are 5.5 for NCR247 and 11.27 for NCR335 at $\mathrm{pH}=7.4$. Although the two peptides are representatives of the same family of AMPs and have similar structures, there is huge difference in the range of spectrum and they possess different efficiency as well. (The MIC value of NCR335 is more than 5 times smaller than in case of NCR247 for E. coli MDS42 strain.) The reasons for this difference and their proper mode of action are not solved yet.

The disintegration of bacterial membrane upon peptide treatment has already been suggested because of the uptake of the membrane-impermeable PI dye by $S$. meliloti bacteria (Tiricz et al. 2013). Here we demonstrated the membranedestroying activity of NCR247 and NCR335 on living E. coli bacteria by performing high-resolution AFM images. Changes in the roughness of the bacterial cell envelope the appearance of protruding structures - were observed, that may indicate the breaking of the membrane integrity. This was also confirmed by detecting the uptake of PI dye (Fig. 1). 3.2 $\mu \mathrm{M}$ solution of NCR335 killed almost all the bacteria and as a consequence, most bacteria detached from the mica surface, while NCR2 47 at $16.6 \mu \mathrm{M}$ concentration caused only one order of magnitude decrease in the cell number (Fig. 2). Nevertheless, the cells that stayed on the PLL-treated mica surface showed similar morphology after both peptide treatments (Fig. 3 and 4). Similar changes in the surface corrugation of bacterial cell envelopes have been demonstrated in earlier AFM studies with other antimicrobial peptides, like polymyxin B and peptide CM15 treatments on E. coli and P. aeruginosa cells (Fantner et al. 2010; Lu et al. 2014).

Gram-negative bacteria (such as E. coli) have an outer membrane and a plasma membrane with a thin layer of peptidoglycan between them, and thick layer of lipopolysaccharide on the outer membrane surface (Lienkamp et al. 2009). Although AFM allows us to obtain images and track the changes of the intact bacterial surface in very good resolution, it is 


\section{Before treatment}

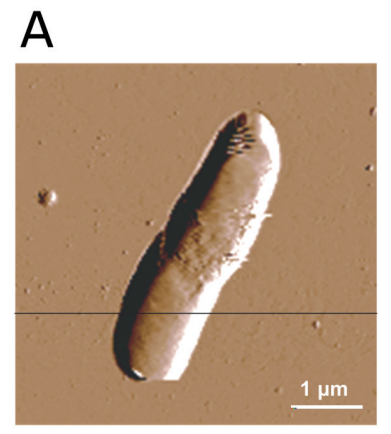

B

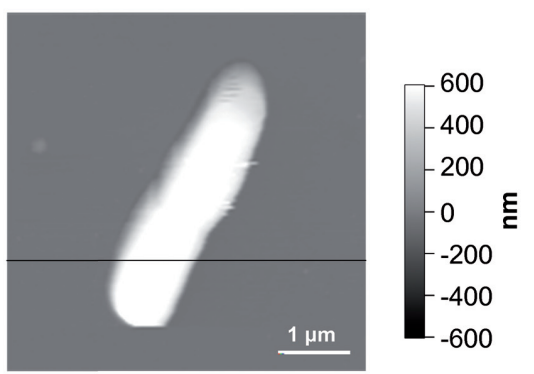

C

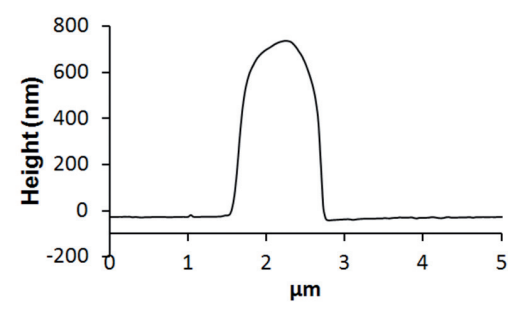

\section{3 hours of NCR335 treatment}
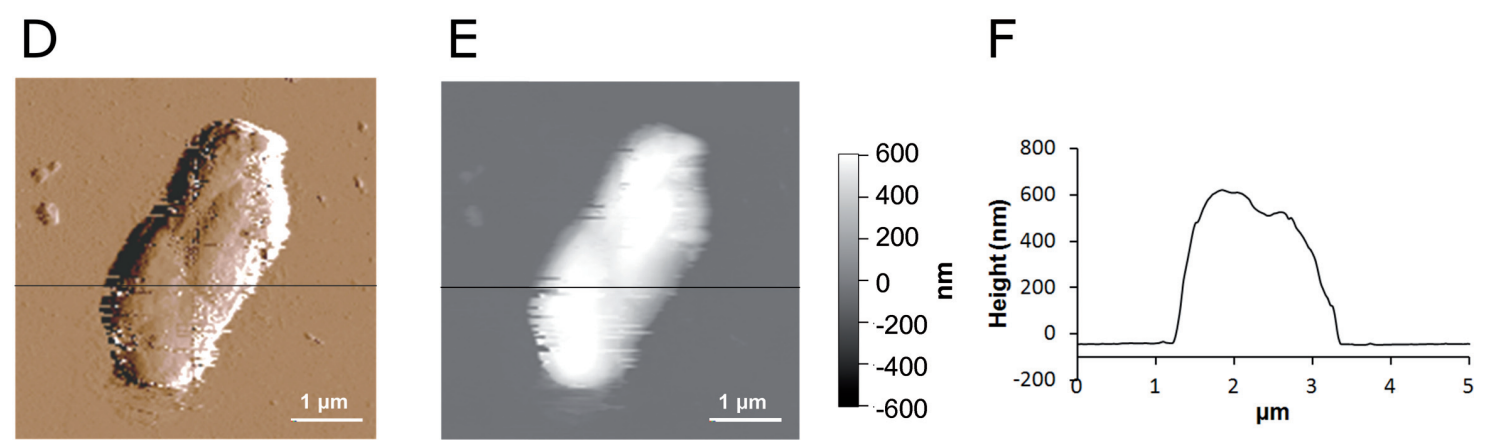

Figure 4. The effect of NCR335 peptide of $3.2 \mu \mathrm{M}$ concentration on the morphology of intact E. coli cells during a typical 3-hour experiment. Amplitude and height images are shown together with height profiles corresponding to the black line assigned on the images. Images $\left(5 \times 5 \mathrm{~m}^{2}\right)$ of the same cells were taken before $(\mathbf{A}, \mathbf{B}, \mathbf{C})$ and after $(\mathbf{D}, \mathbf{E}, \mathbf{F})$ the peptide treatment.

not enough to interpret the measurements, considering the complexity of mechanism of action of AMPs. We do not get any information about the targets of the peptide and how they change the permeability of the cell envelope.

Model membranes and natural membranes may provide detailed information about these peptide-membrane interactions. Natural membrane patches isolated from bacteria may imitate the complexity of cellular systems. The presence of "lipid rafts" has been revealed in Gram-negative (E. coli) and Gram-positive (B. subtilis) bacterial strains recently (López et al. 2010; Barák et al. 2013). Therefore, the incorporation of "membrane rafts" in the studies may lead special consequences. Indeed, the importance of functional microdomains and a preference of lipid regions have already been suggested by Shaw and his co-workers (Shaw et al. 2006). In this study, purple membrane of $H$. salinarum was used as a model of membrane domains, where the tightly packed large protein region is surrounded by lipid regions (Rico et al. 2011).

The plant-derived NCR247 showed similar effects as indolicidin: it aggregated in small spots on the membrane, and created a transient layer with half of the height of the membrane disk. In contrast, NCR335 seemed to solve the edges of the patch without the emergence of the thin layer, and possessed more robust aggregating tendency (Fig. 5-7). In all cases, the surface roughness of the membranes increased. The preference to the membrane edges may be interpreted by the amphipathic nature of AMPs. Their cationic groups allow the interaction and binding to the lipids that are more accessible at the edges of purple membrane discs (Rico et al. 2011). Based on the height of the appearing and extending transient layer $(3-4 \mathrm{~nm})$, it is probably, that it is a monolayer of lipids stabilized by peptides. Similar "membrane-thinning" phenomena have already been described by studies carried out on supported lipid bilayers (with different compositions) with a few peptides, such as Polymixin B, MSI-78 and indolicidin (Schröder et at. 1992; Mecke et al. 2005; Shaw et al. 2006, 2008; Végh et al. 2011). Models generally explain this effect by peptide intercalation between the lipid headgroups, supporting greater mobility of lipid chains, disorganizing the original membrane structure and forming the observed transient layer, where the top monolayer may be replaced by peptides (Mecke et al. 2005; Shaw et al. 2008). Our results further confirm the suggestion that the target site of AMPs in the cytoplasmic membranes is the lipid matrix: the small cationic molecules are attracted by the negatively charged 
A

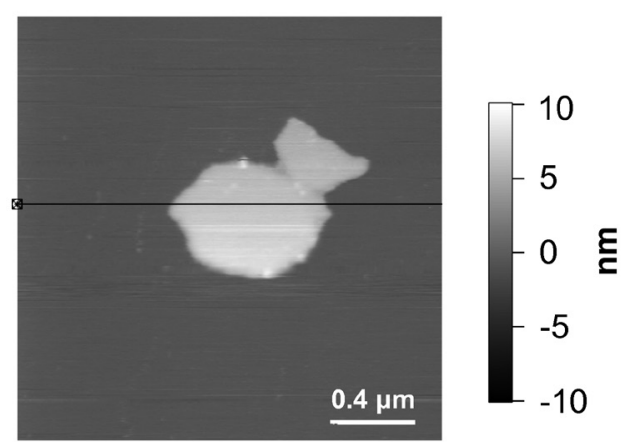

B

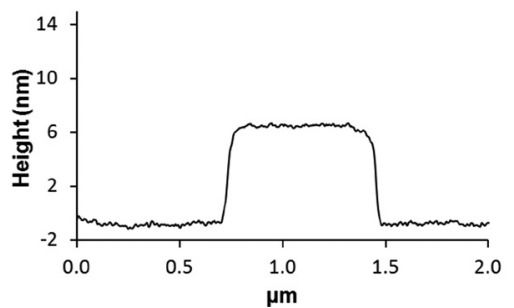

C

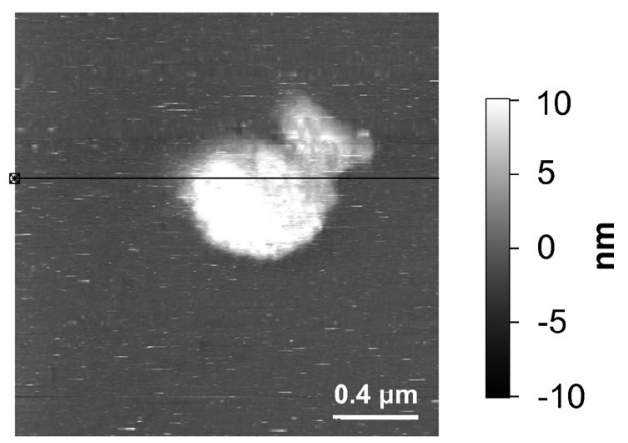

D

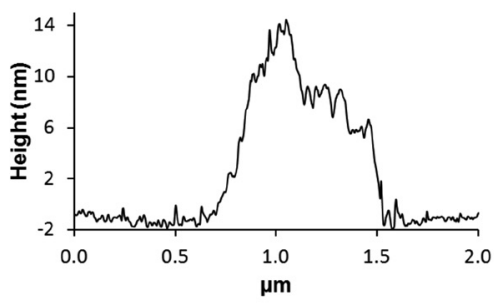

Figure 5. Effect of NCR335 on purple membrane of $H$. salinarum at $0(\mathbf{A})$ and $3.2 \mu \mathrm{M}(\mathbf{C})$ concentrations with sections $(\mathbf{B}, \mathbf{D})$. The images are $2 \times 2 \mu \mathrm{m}^{2}$. The same membrane disks are presented before $(A, B)$ and after $(C, D)$ peptide treatment.

A

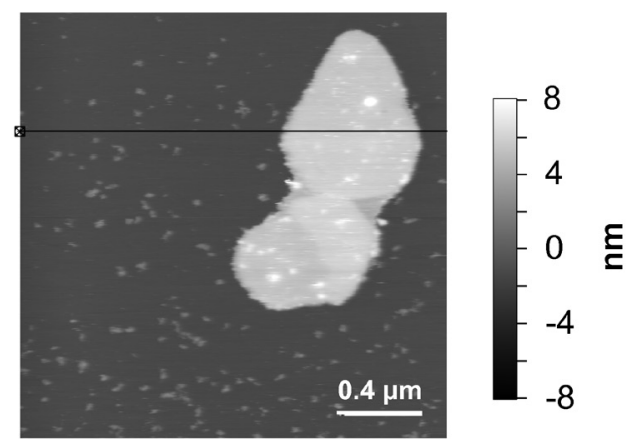

B

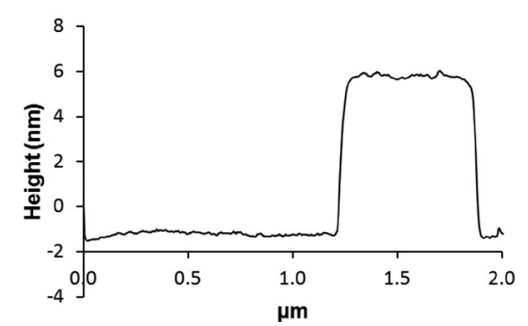

C

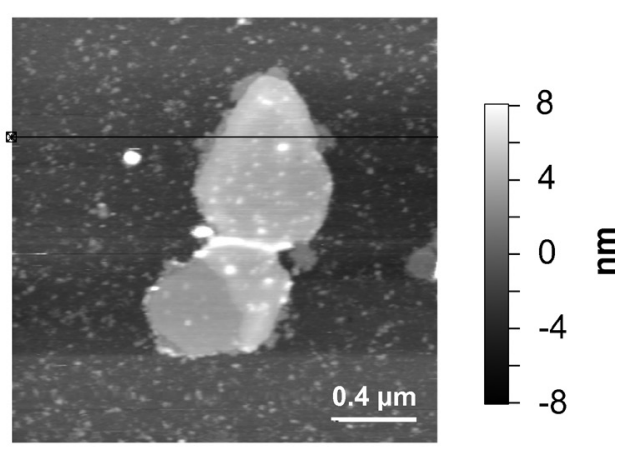

D

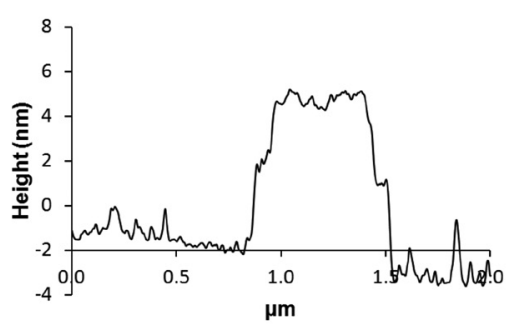

Figure 6. Effect of NCR247 on purple membrane of H. salinarum at $0(\mathbf{A})$ and $16.6 \mu \mathrm{M}(\mathbf{C})$ concentrations with sections (B,D). The images are $2 \times 2 \mu \mathrm{m}^{2}$. The same membrane disks are presented before $(A, B)$ and after $(C, D)$ peptide treatment. 
A
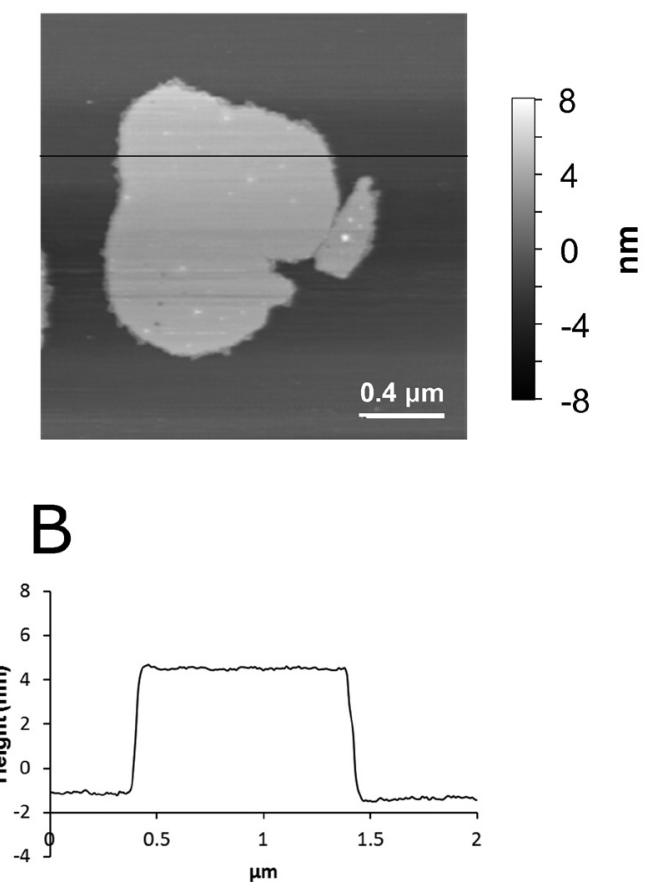
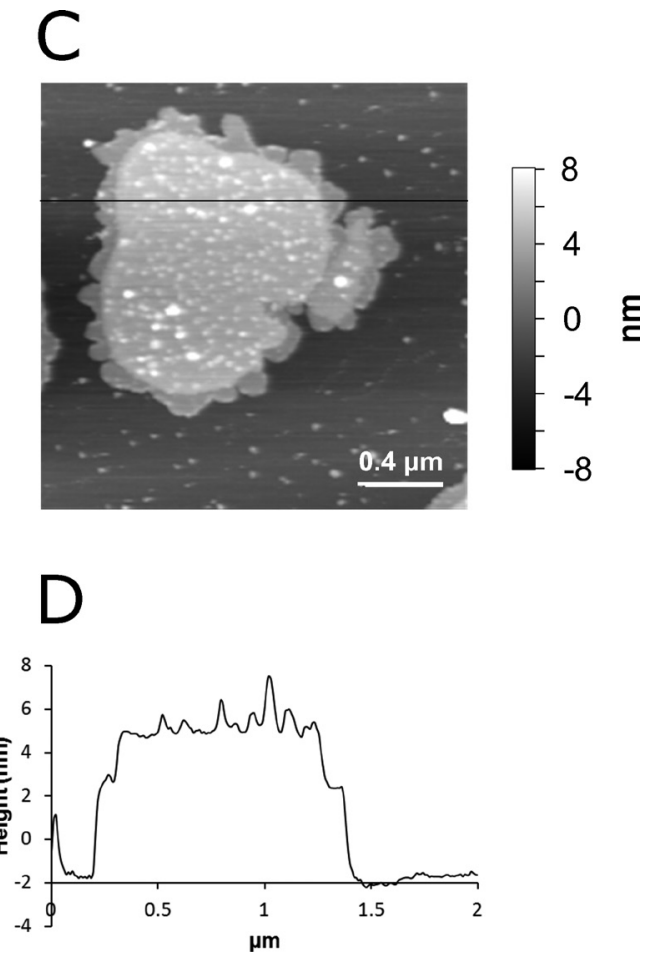

Figure 7. Indolicidin treatment of a purple membrane patch of $H$. salinarum at $0(\mathbf{A})$ and $15 \mu \mathrm{g} / \mathrm{ml}(\mathbf{C})$ concentrations. Height images $(\mathrm{A}, \mathrm{C})$ and sections $(\mathrm{B}, \mathrm{D})$ are presented. The images are $2 \times 2 \mu \mathrm{m}^{2}$.

lipids on the outer part of the bacterial membranes (Teixeira et al. 2012). For defensins, having similar structure to NCR peptides (small size and the presence of stabilizing disulphide bridges), the high affinity to negatively charged phospholipids and the permeabilizing activity against phospholipid vesicles has already been proved (Ganz 2003). Based on the structural resemblance between defensins and NCRs, one may expect similarity in their mode of action, as well. Indeed, in case of NCR247 we demonstrated strong preference to the lipid region of a natural membrane domain. Interestingly, according to our measurements NCR247 showed similar effect to indolicidin that is a member of another AMP family with rather different structure, while NCR335 possess another sort of mechanism of action on purple membrane patches. This may be a reason for the different efficiency and spectrum of their antimicrobial activity.

In conclusion, our results verified the concept that the first target of NCR peptides is probably the bacterial cell envelope. On intact $E$. coli bacteria, both peptides caused increase in the surface roughness indicating the damage of the bacterial cell envelope. From the experiments carried out on purple membranes, it is clear that the three types of antimicrobial peptides (that can all cause lysis of $E$. coli) prefer to disrupt the membrane structure at the periphery regions where lipids are probably more accessible. The membrane-disorganizing effect of NCR247 and indolicidin are manifested in the appearance of thin transient layers, while NCR335 exhibits other type of interaction with a more robust aggregating tendency on the membrane surface. Further investigation is needed to understand the details that lead to the differences in the antimicrobial activity of NCR247 and NCR335, despite their similar structure.

Acknowledgement. The work was supported by the Hungarian research grant PD OTKA 112509, the „Lendület” Program of the Hungarian Academy of Sciences, as well as by the "SYM-BIOTICS" Advanced Grant of the European Research Council (grant number: 269067).

\section{References}

Barák I., Muchová K. (2013): The role of lipid domains in bacterial cell processes. Int. J. Mol. Sci. 14, 4050-4065 http://dx.doi.org/10.3390/ijms14024050

Brogden K. A. (2005): Antimicrobial peptides: pore formers or metabolic inhibitors in bacteria? Nat. Rev. Microbiol. 3, $238-250$

http://dx.doi.org/10.1038/nrmicro1098

Boman H. G. (1995): Peptide antibiotics and their role in innate immunity. Annu. Rev. Immunol. 13, 61-92 
http://dx.doi.org/10.1146/annurev.iy.13.040195.000425

Butt H. J., Jaschke M. (1995): Calculation of thermal noise in atomic force microscopy. Nanotechnology 6, 1-7 http://dx.doi.org/10.1088/0957-4484/6/1/001

Casuso I., Kodera N., Le Grimmelec C., Ando T., Scheuring S. (2009): Contact-mode high-resolution high-speed atomic force microscopy movies of the purple membrane. Biophys. J. 97, 1354-1361 http://dx.doi.org/10.1016/j.bpj.2009.06.019

Dague E., Alsteens D., Latgé J., Verbelen C., Raze D., Baulard A. R., Dufrene Y. F. (2007): Chemical force microscopy of single live cells. Nano Lett. 7, 3026-3030 http://dx.doi.org/10.1021/nl071476k

Dufrene Y. F., Lee G. U. (2000): Advances in the characterization of supported lipid films with atomic force microscope. Biochim. Biophys. Acta 1509, 14-41 http://dx.doi.org/10.1016/S0005-2736(00)00346-1

Dufrene Y. F. (2008): Towards nanomicrobiology using atomic force microscopy. Nat. Rev. Microbiol. 6, 674-680 http://dx.doi.org/10.1038/nrmicro1948

Epand R. M., Vogel H. J. (1999): Diversity of antimicrobial peptides and their mode of action. Biochim. Biophys. Acta 1462, 11-28 http://dx.doi.org/10.1016/S0005-2736(99)00198-4

Fantner G. E., Barbero R. J., Gray D. S., Belcher A. M. (2010): Kinetics of antimicrobial peptide activity measured on individual bacterial cells using high-speed atomic force microscopy. Nat. Nanotechnol. 5, 280-285 http://dx.doi.org/10.1038/nnano.2010.29

Farkas A., Maróti G., Dürgő H., Györgypál Z., Lima R. M., Medzihradszky K. F., Kereszt A., Mergaert P., Kondorosi É. (2014): Medicago truncatula symbiotic peptide NCR247 contributes to bacteroid differencitiation through multiple mechanisms. Proc. Natl. Acad. Sci. USA 111, 5183-5188 http://dx.doi.org/10.1073/pnas.1404169111

Florin E. L., Rief M., Lehmann H., Ludwig M., Dornmair C., Moy V. T., Gaub H. E. (1995): Sensing specific molecular interactions with the atomic force microscope. Biosens. Bioelectron 10, 895-901 http://dx.doi.org/10.1016/0956-5663(95)99227-C

Francius G., Domenech O., Mingeot-Leclercq M. P., Dufrene Y. F. (2008): Direct observation of Staphylococcus aureus cell wall digestion by lysotaphin. J. Bacteriol. 190, 7904-7909 http://dx.doi.org/10.1128/JB.01116-08

Ganz T. (2003): Defensins: antimicrobial peptides of innate immunity. Nat. Rev. Immunol. 3, 710-720 http://dx.doi.org/10.1038/nri1180

Haag F. A., Kerscher B., Dall'Angelo S., Sani M., Longhi R., Baloban M., Wilson H. M., Mergaert P., Zanda M., Ferguson G. P. (2014): Role of cysteine residues and disulfide bonds on the activity of a legume root nodule-specific, cysteine-rich peptide. J. Biol. Chem. 287, 10791-10798 http://dx.doi.org/10.1074/jbc.M111.311316

Huang H. W. (2006): Molecular mechanism of antimicrobial peptides: The origin of cooperativity. Biochim. Biophys. Acta 1758, 1292-1302 http://dx.doi.org/10.1016/j.bbamem.2006.02.001

Hutter J. L., Bechhoefer J. (1993): Calibration of atomic-force microscope tips. Rev. Sci. Instrum. 64, 1868-1873 http://dx.doi.org/10.1063/1.1143970

Lanyi J. K. (2004): Bacteriorhodopsin. Annu. Rev. Physiol. 66, 665-688

http://dx.doi.org/10.1146/annurev.physiol.66.032102.150049

Lázár V., Singh, G. P., Spohn, R., Nagy, I., Horváth, B., Hrtyan, M., Busa-Fekete, R., Bogos, B., Méhi, O., Csörgö, B. et al. (2013): Bacterial evolution of antibiotic hypersensitivity. Mol. Sys. Biol. 9, 700 http://dx.doi.org/10.1038/msb.2013.57

Lehrer R. I., Barton A., Daher K. A., Harwig S. S. L., Ganz T., Selsted M. E. (1989): Interaction of human defensins with Escherichia coli. Mechanism of bacterial activity. J. Clin. Invest. 84, 553-561 http://dx.doi.org/10.1172/JCI114198

Lienkamp K., Kumar K., Som A., Nüsslein K., Tew G. N. (2009): „Double selective" antimicrobial polymers: How do they differentiate between bacteria? Chem. Eur. J. 15, 11710-11714 http://dx.doi.org/10.1002/chem.200802558

López D., Kolter R. (2010): Functional microdomains in bacterial membranes. Gene. Dev. 24, 1893-1902 http://dx.doi.org/10.1101/gad.1945010

Lu S., Walters G., Parg R., Dutcher J. R. (2014): Nanomechanical response of bacterial cells to cationic antimicrobial peptides. Soft Matter. 10, 1806-1815 http://dx.doi.org/10.1039/c3sm52801d

Maróti G., Kereszt A:, Kondorosi É., Mergaert P. (2011): Natural roles of antimicrobial peptides in microbes, plants and animals. Res. Microbiol. 162, 363-374 http://dx.doi.org/10.1016/j.resmic.2011.02.005

Mecke A., Lee D., Ramamoorthy A., Orr B. G., Holl M. M. B. (2005): Membrane thinning due to antimicrobial peptide binding: An atomic force microscopy study of MSI-78 in lipid bilayers. Biophys. J. 89, 4043-4050 http://dx.doi.org/10.1529/biophysj.105.062596

Mergaert P., Nikovics K., Kelemen Z., Munoury N., Vaubert D., Kondorosi A., Kondorosi E. (2003): A novel family in Medicago truncatula consisting of more than 300 nodule-specific genes coding for small, secreted polypeptides with conserved cysteine motifs. Plant. Physiol. 132, 161-173 http://dx.doi.org/10.1104/pp.102.018192

Mergaert P., Uchiumi T., Alunni B., Evanno G., Cheron A., Catrice O., Mausset A., Barloy-Hubler F., Galibert F., Kondorosi A., Kondorosi E. (2006): Eukaryotic control on bacterial cell cycle and differentiation in the Rhizobium-legume symbiosis. Proc. Natl. Acad Sci. USA 103, 5230-5235 http://dx.doi.org/10.1073/pnas.0600912103

Meyer R. L., Zhou X., Tang L., Arpanaei A., Kingshott P., Besenbacher F. (2010): Immobilisation of living bacteria for AFM imaging under physiological conditions. Ultramicroscopy 110, 1349-1357 http://dx.doi.org/10.1016/j.ultramic.2010.06.010

Müller D. J., Schabert F. A., Büldt G., Engel A. (1995): Imaging purple membranes in aqueous solutions at sub-nanometer resolution by atomic force microscopy. Biophys. J. 68, $1681-1686$ http://dx.doi.org/10.1016/S0006-3495(95)80345-0

Müller D. J. Sass H. J., Müller S. A., Büldt G., Engel A. (1999): Surface structure of native bacteriorhodopsin depend on the 
molecular packing arrangement in the membrane. J. Mol. Biol. 285, 1903-1909 http://dx.doi.org/10.1006/jmbi.1998.2441

Müller D. J., Heymann J. B., Oesterhelt F., Möller C., Gaub H., Büldt G., Engel A. (2000): Atomic force microscopy of native purple membrane. Biochim. Biophys. Acta 1460, 27-38 http://dx.doi.org/10.1016/S0005-2728(00)00127-4

Oesterhelt D., Stoeckenius W. (1971): Rhodopsin-like protein from the purple membrane of Halobacterium halobium. Nat. Rev. New Biol. 233, 569-572

Oesterhelt D., Stoeckenius W. (1974): Isolation of the cell membrane of Halobacterium halobium and its fraction into red and purple membrane. Method. Enzymol. 31, 667-678 http://dx.doi.org/10.1016/0076-6879(74)31072-5

Ördögh L., Vörös A., Nagy I., Kondorosi É., Kereszt A. (2014): Symbiotic plant peptides eliminate Candida albicans both in vitro and in epithelial infection model and inhibit the proliferation of immortalized human cells. Biomed. Res. Int. 2014, 320796 http://dx.doi.org/10.1155/2014/320796

Peters B. M., Shirtliff M. E., Jabra-Rizk M. A. (2010): Antimicrobial peptides: primeval molecules or future drugs? Plos. Pathog. 6, e1001067 http://dx.doi.org/10.1371/journal.ppat.1001067

Pilbat A. M., Szegletes Z., Kóta Z., Ball V., Schaaf P., Voegel J. C., Szalontai B. (2007): Phospholipid bilayers as biomembranelike barriers in layer-by-layer polyelectrolyte films. Langmuir 23, 8236-8242 http://dx.doi.org/10.1021/la700839p

Pósfai G., Plunkett G. 3rd, Fehér T., Frisch D., Kell G. M., Umenhoffer K., Stahl B., Sharma S. S., de Arruda M., Burland V., Harcum S. W., Blattner F. R. (2006): Emergent properties of reducedgenome Escherichia coli. Science 312, 1044-1046 http://dx.doi.org/10.1126/science.1126439

Rico F., Su C., Scheuring S. (2011): Mechanical mapping of single membrane proteins at submolecular resolution. Nano Lett. 11, 3983-3986 http://dx.doi.org/10.1021/nl202351t

Schröder G., Brandenburg K., Seydel U. (1992): Polymixin B induces transient permeability fluctuations in asymmetric planar lipopolysaccharide/phospholipid bilayers. Biochemistry 31, 631-638 http://dx.doi.org/10.1021/bi00118a001

Selsted M. E., Novotny M. J., Morris W. L., Tang Y. Q., Smith W., Cullor J. S. (1992): Indolicidin, a novel bactericidal tridecapeptide amide from neutrophils. J. Biol. Chem. 267, 4292-4295

Shaw J. E., Alattia J. R., Verity J. E., Privé G. G., Yip C. M. (2006): Mechanism of antimicrobial peptide action: Studies of indolicidin assembly at model membrane interfaces by in situ atomic force microscopy. J. Struct. Biol. 154, 42-58 http://dx.doi.org/10.1016/j.jsb.2005.11.016

Shaw J. E., Epand F. F., Hsu J. C. Y., Mo G. C. H., Epand R. M., Yip C. M. (2008): Cationic peptide-induced remodelling of model membranes: Direct visualization by in situ atomic force microscopy. J. Struct. Biol. 162, 121-138 http://dx.doi.org/10.1016/j.jsb.2007.11.003

Simons K., Ikonen E. (1997): Functional rafts in cell membranes. Nature 387, 569-572 http://dx.doi.org/10.1038/42408

Sochacki K. A., Barns K. J., Bucki R., Weisshaar C. (2011): Real-time attack on single Escherichia coli cells by the human antimicrobial peptide LL-37. Proc. Natl. Acad. Sci. USA 108, E77-81 http://dx.doi.org/10.1073/pnas.1101130108

Sonnino S., Prinetti A. (2013): Membrane domains and the „lipid raft" concept. Curr. Med. Chem. 20, 4-21

Teixeira V., Feio M. J., Bastos M. (2012): Role of lipids in the interaction of antimicrobial peptides with membranes. Prog. Lipid Res. 51, 149-177 http://dx.doi.org/10.1016/j.plipres.2011.12.005

Tiricz H., Szűcs A., Farkas A. Pap B., Lima R. M., Maróti G., Kondorosi É., Kereszt A. (2013): Antimicrobial nodule-specific cysteine-rich peptides induce membrane depolarization-associated changes in the transcriptome of Sinorhizobium meliloti. Appl. Environ. Microbiol. 79, 6737-6746 http://dx.doi.org/10.1128/AEM.01791-13

Touhami A., Jericho M. H., Beveridge T. J. (2004): Atomic force microscopy of cell growth and division in Staphylococcus aureus. J. Bacteriol. 186, 3286-3295 http://dx.doi.org/10.1128/JB.186.11.3286-3295.2004

Vaara M., Vaara T. (1983): Polycations as outer membrane-disorganizing agents. Antimicrob. Agents Ch. 24, 114-122 http://dx.doi.org/10.1128/AAC.24.1.114

Vadillo-Rodriguez V., Schooling S. R., Dutcher J. R. (2009): In situ characterization of differences in the viscoelastic response of individual Gram-negative and Gram-positive bacterial cells. J. Bacterial. 191, 5518-5525 http://dx.doi.org/10.1128/JB.00528-09

Van de Velde W., Zehirov G., Szatmari A., Debreczeny M., Ishihara H., Kevei Z., Farkas A., Mikulass K., Nagy A., Tiricz H. et al. (2010): Plant peptides govern terminal differentiation of bacteria in symbiosis. Science 327, 1122-1126 http://dx.doi.org/10.1126/science.1184057

Végh A. G., Nagy K., Bálint Z., Kerényi Á., Rákhely G., Váró G., Szegletes Z. (2011): Effect of antimicrobial peptide-amide: indolicidin on biological membranes. J. Biomed. Biotechnol. 2011, 670589 http://dx.doi.org/10.1155/2011/670589

Yamashita H., Voitvhovsky K., Uchihashi T., Contera S. H., Ryan J. F., Ando T. (2009): Dynamics of bacteriorhodopsin 2D crystal observed by high-speed atomic force microscopy. J. Struct. Biol. 167, 153-158 http://dx.doi.org/10.1016/j.jsb.2009.04.011

Received: September 22, 2014

Final version accepted: January 12, 2015

First published online: February 12, 2015 